University of Nebraska - Lincoln

DigitalCommons@University of Nebraska - Lincoln

Agronomy \& Horticulture -- Faculty Publications

Agronomy and Horticulture Department

November 1999

\title{
Post-Green Revolution Trends in Yield Potential of Temperate Maize in the North-Central United States
}

D. N. Duvick

lowa State University

Kenneth G. Cassman

University of Nebraska-Lincoln, kcassman1@unl.edu

Follow this and additional works at: https://digitalcommons.unl.edu/agronomyfacpub

Part of the Plant Sciences Commons

Duvick, D. N. and Cassman, Kenneth G., "Post-Green Revolution Trends in Yield Potential of Temperate Maize in the North-Central United States" (1999). Agronomy \& Horticulture -- Faculty Publications. 96. https://digitalcommons.unl.edu/agronomyfacpub/96

This Article is brought to you for free and open access by the Agronomy and Horticulture Department at DigitalCommons@University of Nebraska - Lincoln. It has been accepted for inclusion in Agronomy \& Horticulture -Faculty Publications by an authorized administrator of DigitalCommons@University of Nebraska - Lincoln. 


\title{
Post-Green Revolution Trends in Yield Potential of Temperate Maize in the North-Central United States
}

\author{
D. N. Duvick and K. G. Cassman*
}

\begin{abstract}
This paper addresses the question of whether there has been an increase in yield potential of maize (Zea mays L.) hybrids released in the north-central United States since the advent of the "Green Revolution" that began in the late 1960s. Because there are few published data about hybrid growth rates and yield-determining plant traits when grown at yield potential levels, we attempt to address this issue indirectly by evaluation of maize breeding efforts, changes in plant traits of commercial hybrids, and by comparison of statewide average yield trends and yield trends in sanctioned yield contests. On the basis of these sources of information and a definition of yield potential as the yield that can be achieved with an adapted hybrid when grown without obvious stress of any kind, we found that there is conflicting evidence to support the hypothesis that maize yield potential has increased. We recommend experimental approaches to quantify and investigate the determinants of maize yield potential in the north-central United States and for use in breeding hybrids with greater yield potential.
\end{abstract}

$\mathrm{A}^{\mathrm{t}}$ THOUGH THERE IS CONSIDERABLE UNCERTAINTY in predictions of global requirements for food and feed grains during the next $30 \mathrm{yr}$, there is no doubt that total requirements will increase substantially. Expansion of cereal production on land not presently under cultivation is limited by the need to preserve remnant natural ecosystems and by losses of arable land to urban, industrial, and recreational development - trends that are expected to continue as population increases. Given these constraints on the availability of arable land, crop yield potential will be a primary factor governing the nature of agricultural systems in the next century. At issue is the degree of intensification in crop production systems that will be possible, which in turn, will determine the amount of land and natural resources that can be spared for other uses (Waggoner, 1994).

One global food supply-demand model predicts that global demand for maize will increase from 526000000 to 784000000 t from 1993 to 2020, with most of the increased demand coming from developing countries (Rosegrant et al., 1999). Assuming no increase in maize production area, an annual growth rate in maize yield of $\approx 1.5 \%$ will be needed to meet this demand; however, from 1982 to 1994 , the yield growth rate for maize was $1.2 \%$ worldwide, but only $1.0 \%$ in developed countries as a group, which account for the majority of total maize production. Understanding the factors contributing to these yield trends is therefore fundamental to efficient allocation of research investments to sustain the needed increase. Although it is clear that genetic improvement has contributed significantly to maize yield advances in

D.N. Duvick, Dep. of Agronomy, Iowa State University, P.O. Box 446, Johnston, IA 50131; K.G. Cassman, Dep. of Agronomy, Univ. of Nebraska, Lincoln, NE 68583-0915. Received 28 Dec. 1998. *Corresponding author (kcassman@unl.edu).

Published in Crop Sci. 39:1622-1630 (1999). farmers' fields, it is not clear that breeders have been successful in achieving greater yield potential as defined by Evans (1993), which is the yield of a cultivar when grown in environments to which it is adapted, with nonlimiting nutrients and water, and effective control of pests, diseases, weeds, lodging, and other stresses.

Unfortunately, there are few published studies in which plant traits and physiological processes that govern maize growth and development were measured in fields that attain yield potential levels of modern hybrids. Although on-farm yields of 21000 to $22000 \mathrm{~kg}$ $\mathrm{ha}^{-1}$ have been regularly reported in the north-central United States since the mid 1970s (Robertson et al., 1978; Nelson and Reetz, 1986), there are few data on plant performance at these yield levels. Because direct measurements of maize growth and development at yield potential levels under field conditions are lacking, we attempt to identify the factors that have contributed to the maize yield increases in the post-Green Revolution era by evaluating maize breeding efforts, changes in plant traits in a historical series of commercial maize hybrids widely used in the north-central United States, and trends in the highest yields obtained by farmers in rainfed and irrigated yield contests.

\section{Breeding Methods and Investment in Maize Improvement}

About $95 \%$ of total expenditures for maize improvement in the United States are made by private-sector seed companies (Frey, 1996). By far the most important selection criteria used by commercial maize breeders are yield and yield stability. While other agronomic traits such as pest resistance, plant height, and lodging are also taken into account, primary selection emphasis is given to direct measurement of yield from individual performance trials, with increasing numbers of sites and years in the testing process as new hybrids move closer to potential commercialization. A key point here is that there are no proxies for direct yield measurements at all stages of hybrid development.

Hybrid development and commercial release is a sequential selection process that depends on numbers and scale. Inbred lines are produced with rigorous selection for multiple traits with additive inheritance. New inbred lines are continually being developed from a large germplasm pool with sufficient diversity for development of improved hybrids (Duvick, 1981). The inbred lines are used to make thousands of experimental hybrids which are grown in small-plot yield trials for a period of 3 to $5 \mathrm{yr}$ at 25 or more on-farm locations per hybrid per year. The survivors (not more than one per several thousand) are conditionally released on a small scale for

Abbreviations: GDD, growing degree days; OPV, open-pollinated variety. 
rigorous on-farm yield testing by farmers. These onfarm trials involve side-by-side comparisons of several hybrids planted in strips of several rows each in a field managed by the farmer. Grain is harvested by combine from a measured length of each hybrid strip, augured into a portable scale wagon, and then tested for moisture content and test weight. Hybrids that achieve high and stable yields in these strip trials are then considered for broad-scale commercial release and are often sold in several states.

Whereas the entire process from the initial hybrid cross to commercial release typically required 5 to $7 \mathrm{yr}$ or more, the amount of time has been reduced to $5 \mathrm{yr}$ or less in recent years. Of the hybrids that reach commercialization, a small number become popular hybrids that are widely used by farmers. Commercially successful hybrids have therefore undergone a final selection by thousands of farmers who have decided that a particular hybrid is "best" for their farm environment. Such hybrids may maintain their popularity for several years before being replaced by a newer hybrid. In the end, farmer preferences in the marketplace determine the success or failure of each hybrid, and the length of time that a hybrid remains popular. On average, farmers give widespread approval to not more than one in five of all newly released hybrids.

Despite the continued consolidation of commercial seed companies, the direct investment in maize breeding has increased nearly four fold since the 1970s (Table 1). Although a considerable portion of the increase in the past 10 to $15 \mathrm{yr}$ is associated with greater emphasis on molecular genetics and development of transgenic hybrids, this trend has not reduced the size and scale of the field breeding effort essential for breeding and selection of improved hybrids. Frey (1996) counted 418 maize breeders engaged in cultivar development (field breeding) in 1994, as compared with 250 breeders in the 1980 s and 160 breeders in the 1970s (Table 1). We estimate that breeders are presently making annual selections from about three million hybrid plots each year at 1000 different testing locations in the United States. Of this total effort, $80 \%$ is focused on the central and north-central prairie states where most U.S. maize production is located.

\section{Changes in Maize Hybrids \\ Turnover of Commercial Maize Hybrids}

In 1981, U.S. corn breeders from the leading seed companies reported that hybrids usually stayed on the market for an average of $7 \mathrm{yr}$, but that they expected this lifetime to become shorter in future years (Duvick, 1984a). This collective conclusion was supported by surveys of inbred use which showed that the leading inbreds of 1970 were no longer used in 1979; they had been replaced by new ones in the span of $9 \mathrm{yr}$. The hybrids made with leading inbreds of the 1970s were replaced by hybrids made with the leading inbreds of the 1980s. Replacement occurred primarily because the newer inbreds produced higher-yielding hybrids, not because the older inbreds (and their hybrids) had succumbed to insect or disease problems.
Table 1. Estimated annual private-sector investment of scientist years (SY), capital, and scale of the hybrid maize selection efforts in the United States during the past three decades.

\begin{tabular}{lcccr}
\hline Period & $\begin{array}{c}\text { Maize } \\
\text { breeders }\end{array}$ & $\begin{array}{c}\text { Operating } \\
\text { costs }\end{array}$ & $\begin{array}{c}\text { Testing } \\
\text { locations }\end{array}$ & $\begin{array}{r}\text { Number of } \\
\text { yield plots }\end{array}$ \\
\hline $1970 \mathrm{~s}$ & 160 & $\$ 40000000$ & 600 & 600000 \\
$1980 \mathrm{~s}$ & 250 & $\$ 62500000$ & 900 & 1200000 \\
$1990 \mathrm{~s}$ & 550 & $\$ 137500000$ & 1000 & $\mathbf{3 0 0 0 0 0 0}$ \\
\hline
\end{tabular}

$\dagger$ Estimates of the numbers of maize breeders are based on data reported by Frey (1996) for the 1990s, Kalton et al. (1989) for the 1980s, and by Pioneer Hi-Bred International (1973-1997). Figures from the latter were adjusted for market share of the U.S. hybrid seed market and assumes a similar ratio of breeders to sales in other companies. Operating costs were based on a value of $\$ 250000$ per $\mathrm{SY}$ in 1993 U.S. dollars as estimated by Frey (1996). Testing locations and yield plots were estimated from the Annual Reports of Pioneer Hi-Bred International (1973-1997) and adjusted for market share of seed sales.

Hybrid turnover is mostly driven by improved performance of newer hybrids with respect to yield and yield stability, and farmers choose to buy them instead of the older hybrids. Strenuous competition among seed corn companies ensures that farmers have ample opportunity to test new hybrids and choose those that genuinely yield more under farm conditions. Hybrid lifetimes have shortened over the decades, and the trend continues, perhaps at a faster rate. Competition among companies is increasing. They introduce improved hybrids at a faster rate, thus causing earlier replacement of older hybrids. Also, seed companies are more ready to discontinue sale of older hybrids with relatively low sales volume. Farmers also are causing faster hybrid turnover. They, like the seed companies, are more profit conscious and wish to plant only the newest and highest-yielding hybrids. They now have better tools and more information for making hybrid comparisons, and they use them. Farmers also show little company loyalty, if it looks like "loyalty" is going to cost them money.

However, there is a new reason for hybrid replacement - the introduction of genetically engineered traits such as herbicide tolerance or resistance to an insect pest or disease. Recent experience in the U.S. Corn Belt indicates that a transgenic form of an existing conventional hybrid containing such traits will quickly replace the nontransgenic versions and decrease the commercial lifetime of the conventional hybrids. However, this effect is likely to be a temporary phenomenon because once these transgenes are spread throughout elite breeding materials, they will become common "background" genes. Breeders will then continue their work of improving yield and stress tolerance via changes in quantitatively inherited traits.

Although hybrid maize in the U.S. Corn Belt has been fortunate in that few insect or disease pests have caused widespread and serious damage, an important exception to this rule was the 1970 epidemic of race T, southern corn leaf blight (Bipolaris maydis Nisikado and Miyabe, Shoemaker). This epidemic was caused by a convergence of susceptible cytoplasm ("T" cytoplasm) and a growing season with climatic conditions favorable for spread of the disease (National Research Council, 1972). Because the epidemic primarily was caused by a susceptible cytoplasm rather than susceptible nuclear genes, it was countered by reproducing the hybrids with 
resistant (non-T) cytoplasms, rather than by introduction of entirely new hybrids. Hence, hybrid pedigrees changed very little as a result of the southern corn leaf blight epidemic (Duvick and Noble, 1978). In contrast, a major change in pedigrees was needed when the European corn borer (Ostrinia nubilalis Huber) moved into the Corn Belt states in the 1940s and 1950s. Replacement hybrids had marginally greater tolerance to the borer. The tolerance was quantitatively inherited and came from Corn Belt dent germplasm rather than from exotic sources.

A second major change in hybrid pedigrees occurred when plant densities were increased markedly in the 1960s to take advantage of higher rates of $\mathrm{N}$ fertilizer. Although some hybrids yielded more when plant populations were increased, others showed no increase or even lost yield at higher plant densities. Farmers gravitated to the hybrids that produced increased yield at higher plant densities, and breeders selected new breeding lines that could take advantage of even higher plant densities.

A few region-specific diseases have caused hybrid replacements on a smaller scale than those that resulted from introduction of the European corn borer and increases in plant density. Maize dwarf mosaic virus in the Mid-South in the 1960s brought about a need for hybrids with tolerance of the virus, until improved herbicides reduced pressure from virus-harboring weeds. Gray leaf spot (Cercospora zeae-maydis Tehon and E.Y. Daniels) has caused replacement of some hybrids in the southern Corn Belt in the 1990s, particularly in conservation tillage systems in which maize residue is not incorporated into soil. But overall, such occurrences are not a major reason for hybrid replacement. Old hybrids have been replaced by new ones primarily because the new hybrids yielded more and did so consistently across locations and years.

\section{Changes in Maize Hybrid Traits and Yielding Ability}

Comparisons of temperate maize hybrids released during the past $60 \mathrm{yr}$ have consistently documented significant genetic gains in rainfed yield (Castleberry et al., 1983; Derieux et al., 1987; Duvick, 1992; Eyhérabide et al., 1994; Ivanovic and Kojic, 1990; Russell, 1991; Tollenaar, 1991). Progress in yield under rainfed conditions has been linear (see below), and genetic gains have been estimated to account for at least $50 \%$ of total yield gain achieved at the farm level. Changes in agronomic practices are responsible for the remainder. The studies are also consistent in finding that rainfed yield gains are associated with increases in tolerance to prevailing biotic and abiotic stresses as summarized by Tollenaar and $\mathrm{Wu}$ (1999) for conditions in Ontario, Canada, and Duvick (1984b, 1992, and 1997) for conditions in Iowa.

A recent investigation evaluated changes in plant traits in a time series of 36 hybrids and one open-pollinated variety (OPV) adapted to Iowa and eastern $\mathrm{Ne}$ braska (Duvick, 1997). The hybrids were bred and introduced during a 60-yr period, from the 1930s to the 1990s. All were widely grown and popular with farmers in their time. Although all hybrids in this study were bred and sold by one company, they are generally representative of all hybrids for this time span in this region. Over the years many other hybrids competed successfully for market share with the hybrids in this study, which implies that the other hybrids also had traits, including high yielding ability, that were desired by farmers at the time.

The hybrids were grown under rainfed conditions in replicated plots at several locations in each of $4 \mathrm{yr}$ from 1991 to 1994. Treatments included the different hybrids and four plant densities $\left(10,30,54\right.$, and $79 \times 10^{3}$ plants $\mathrm{ha}^{-1}$ ). Cultural practices followed recommended practices with regard to nutrients and pest management. Thirty traits were measured in each hybrid and the OPV. Mean values for plant traits of each hybrid were regressed on year of introduction while the OPV arbitrarily was assigned the year 1930. A previous report focused on the changes during the entire 60 -yr period (Duvick, 1997). Examples of these regressions are shown in Fig. 1, and $R^{2}$ values for regression of individual plant traits on year of release, from 1930 to 1991, are provided in Table 2. Our discussion here will focus on the changes that have occurred in the post-Green Revolution era since the late 1960s, using the regression equations to estimate the magnitude of change in each plant trait from 1967 to 1991.

A number of traits have changed markedly since 1967, and most of these changes did not result from direct selection efforts of the breeders (Table 2; Duvick, 1997). Some of these traits would contribute to increased yield potential if all other plant traits remained constant. These include decreased grain protein concentration (Fig. 1a) and a concurrent increase in grain starch (Fig. 1b; McDermitt and Loomis, 1981), decreased tassel size (Fig. 1c; Duncan et al., 1967), a reduction in the number of barren plants at high plant density (shown in Table 2 as ears plant ${ }^{-1}$ ), and a reduced rate of leaf senescence during grain filling ("stay-green") (Table 2). Other traits would be beneficial under abiotic or biotic stress conditions such as the reduction in the anthesis-silking interval at high density, which is an indicator of drought tolerance (Bolanos and Edmeades, 1996), and resistance to damage from second-generation European corn borer. The advantages of still other traits are likely to be dependent on plant density, which in many ways is a form of stress because it imposes greater intra plant competition for resources. These traits include reduced root or stalk lodging, which increase at high plant densities, and an increase in leaf angle (Fig. 1d), which allows greater light penetration into the canopy at the higher leaf area index values that result from closer plant spacing.

Among the traits that did not change, or for which changes were not consistent among the hybrids released since the late 1960s, were ear size and height, kernel weight, growing degree days to anthesis, leaf area per plant, grain oil content, and resistance to damage from first-generation European corn borer. Although tillering and plant height reductions were evident in the earlier period of the hybrid time series from 1930 to 

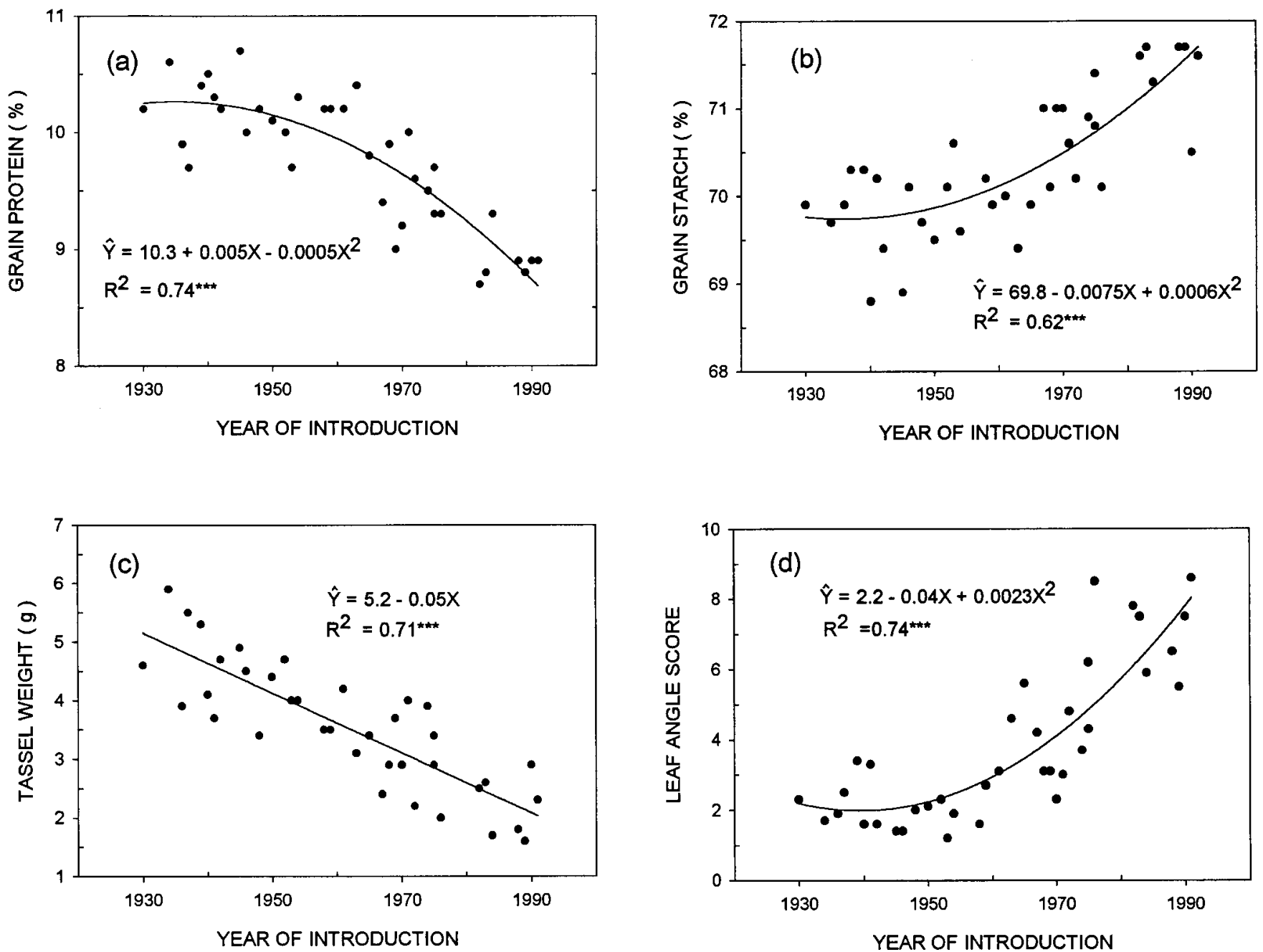

Fig. 1. Changes in (a) grain protein concentration, (b) starch, (c) tassel dry weight, and (d) leaf angle, with an increasing leaf-angle score representing more erect leaf stature, in relation to the year of release for commercial maize hybrids and one open-pollinated variety. Data are from field experiments conducted in central Iowa from 1991 to 1994.

1966, there was little consistent change in these traits in hybrids released subsequent to 1966 . Some of these traits have purposely been held constant by breeders to satisfy demands of farmers or because of the length of the growing season in the north-central United States. Despite the high correlation between late maturity and yield in favorable growing seasons, flowering date and grain moisture at harvest are kept constant because

Table 2. Changes in plant traits of one open-pollinated variety and 36 maize hybrids that were released from 1931-1991. Measurements were taken in field experiments conducted from 1991 to 1994 in Iowa. Modified from Duvick (1997).

\begin{tabular}{|c|c|c|c|c|c|c|}
\hline \multirow[b]{2}{*}{ Trait } & \multirow{2}{*}{$\begin{array}{c}\text { Year } \\
\text { measured }\end{array}$} & \multirow{2}{*}{$\begin{array}{c}\text { Plant } \\
\text { density }\end{array}$} & \multirow[b]{2}{*}{$\boldsymbol{R}^{2} \dagger$} & \multicolumn{3}{|c|}{ Trend-line values } \\
\hline & & & & 1967 & 1991 & Change \\
\hline & & $10^{3} \mathrm{ha}^{-1}$ & & & & $\%$ \\
\hline Ears per plant, no. $\mathbf{p H}^{-1}$ & 1992,1994 & 79 & 0.74 & 0.97 & 1.05 & +8 \\
\hline Tassel dry weight, $\mathrm{g} \mathrm{pH}^{-1}$ & 1992 & all & 0.71 & 3.3 & 2.1 & -36 \\
\hline Grain protein, $\mathbf{g ~ k g}^{-1}$ & 1992 & all & 0.68 & 97 & 87 & -10 \\
\hline Stalk lodging, \%§ & 1991-1994 & all & 0.68 & 8 & 2 & -75 \\
\hline Root lodging, \%§ & 1991-1992 & all & 0.66 & 35 & 15 & -57 \\
\hline Leaf "stay-green", score§ & 1991-1994 & all & 0.66 & 5.1 & 6.6 & +29 \\
\hline Leaf angle, score $\$$ & 1991-1994 & all & 0.65 & 3.6 & 8 & +122 \\
\hline Anthesis-silk interval, GDD\$ & 1991-1994 & 79 & 0.65 & 23 & 6 & -74 \\
\hline Grain starch, $\mathbf{g ~ k g}^{-1}$ & 1992 & all & 0.62 & 703 & 717 & +2 \\
\hline 2nd Eur. corn borer, score§ & 1992,1994 & all & 0.58 & 3.2 & 4.5 & +41 \\
\hline
\end{tabular}

$\dagger$ Proportion of variance explained by linear or quadratic regressions of hybrid plant trait values on year of release.

+ Unless actual density is specified, changes in plant traits are based on the mean of three plant density treatments: 30,54 , and $79 \times 10^{-3}$ plants ha ${ }^{-1}$

$\S$ Percentage of plants lodged or with tillers. Score = visual rating scale of 1 to 9 , where 1 is rapid leaf senescence (poor "stay-green") during grain filling and $9=$ slow leaf senescence (good "stay-green"); $1=$ mostly horizontal leaf display (leaf angle) and $9=$ nearly vertical leaf angle when measured after anthesis; 1 = severe damage from second generation European corn borer and $9=$ no damage from second generation corn borer. GDD $=$ growing degree day $\left({ }^{\circ} \mathrm{C}\right)$. 


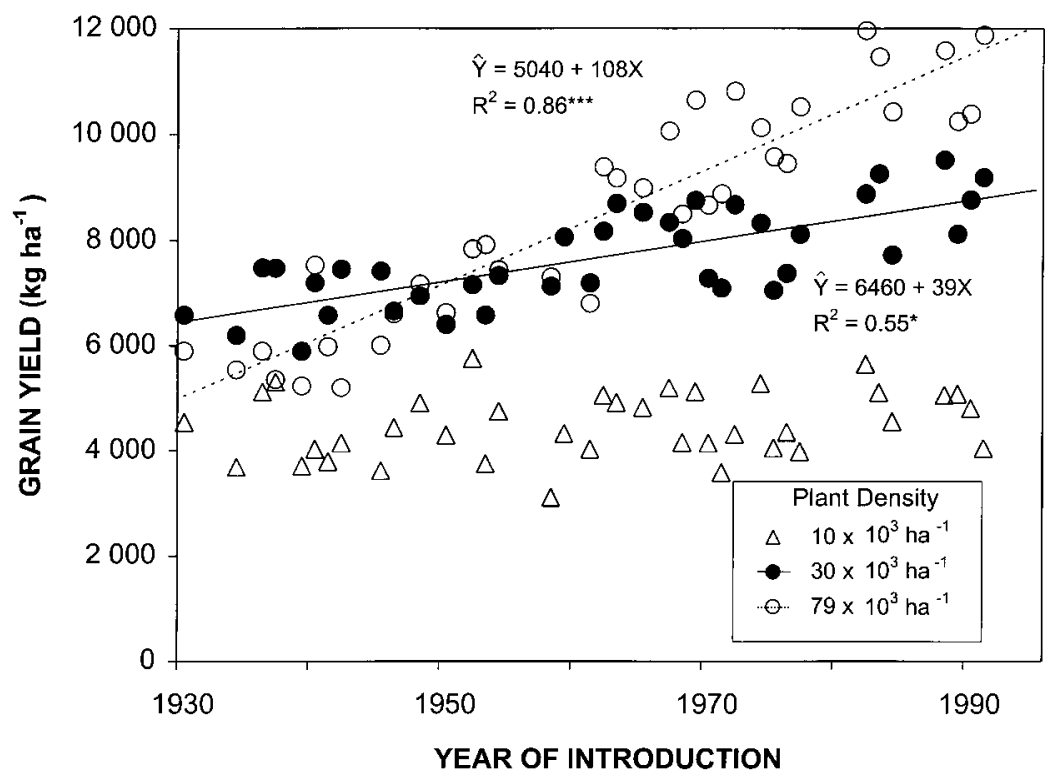

Fig. 2. The relationship between hybrid yield at different plant densities and year of release. Data were obtained from field experiments conducted at three locations in central Iowa in 1994.

later-maturing hybrids are at risk from early frost in some years.

Grain yields of the time-series hybrids have increased linearly with year of release except at very low plant density (Fig. 2). This very low plant density (10 000 plant $\mathrm{ha}^{-1}$ ) is well below that used in any farming operations, past or present, and provides a nearly stress-free environment in most growing seasons. The lack of increase at very low density is consistent with other studies of old and new maize hybrids (Tollenaar and $\mathrm{Wu}, 1999$ ) and reinforces the supposition that some of the changes in the plant traits, such as leaf angle and lodging resistance, confer yield advantages only at high plant density. It is noteworthy that the density of 79000 plants ha ${ }^{-1}$ is closest to the actual density used by today's farmers in the north-central United States. The newer hybrids also achieved greater yields than the older ones in stressful growing seasons, such as in 1991 (hot and dry) and in 1993 (cold and wet), as well as in years with favorable weather, such as in 1992 and 1994 (Fig. 3). For example, the rate of yield gain estimated from the data in 1992, the most favorable year, was $82 \mathrm{~kg} \mathrm{ha}^{-1} \mathrm{yr}^{-1}\left( \pm 6 \mathrm{ha}^{-1}\right.$ $\left.\mathrm{yr}^{-1} \mathrm{SE}\right)$. The rate of gain was $57 \mathrm{~kg} \mathrm{ha}^{-1} \mathrm{yr}^{-1}( \pm 4 \mathrm{~kg}$ $\mathrm{ha}^{-1} \mathrm{yr}^{-1} \mathrm{SE}$ ) as estimated in the unusually cold and wet growing season of 1993, which is $30 \%$ less than the rate of gain estimated from the 1992 data. These differences suggest that the changes in hybrid traits have contributed to yielding ability in stressful as well as in more favorable growing conditions, which is again consistent with the traits that have changed in popular maize hybrids released during the past $30 \mathrm{yr}$ (Table 2).

However, it is important to note that these studies were conducted under rainfed conditions at yield levels that were closer to the average statewide yield levels than to the maximum attainable yields achieved by contest-winning farmers (Fig. 4a). Hence, the rate of genetic gain in yielding ability measured in these studies cannot be attributed to an increase in yield potential without stress. Instead, it may represent the progress breeders have made in conferring greater tolerance to a wide range of biotic and abiotic stresses encountered during the growing season of a typical rainfed maize crop when sown at high plant density. With greater stress tolerance, the newer hybrids have more opportunity to achieve their maximum yield potential by avoiding a number of potential stresses during the growing season.

\section{Maize Yield Trends}

\section{Statewide-Average Yield Trends}

Iowa produces more maize than any other state in the United States and is located in the heart of the north-central region. Nearly all Iowa maize is produced in rainfed systems and most is grown in a 2-yr rotation with soybean (Glycine max L. Merrill). Nebraska is directly west of Iowa and also is a large maize-producing state. Unlike Iowa, irrigated maize systems account for nearly $75 \%$ of total maize production in Nebraska. Moreover, rainfall decreases from east to west across Iowa and Nebraska so that average rainfed maize yields in Nebraska are less than in Iowa.

Despite the differences in climate and water supply, the rate of increase in average maize yield since 1966 has been remarkably similar in both states and in both rainfed and irrigated systems. For example, average farm yield has increased linearly at a rate of $87 \mathrm{~kg} \mathrm{ha}^{-1}$ $\mathrm{yr}^{-1}$ in rainfed Iowa maize systems (Fig. 4a). By comparison, average yield advanced $99 \mathrm{~kg} \mathrm{ha}^{-1} \mathrm{yr}^{-1}$ in rainfed Nebraska systems (Fig. 4b), where rainfall is less abundant than in Iowa. Despite this difference in rainfall, the proportion of variance explained by the linear regression of yield vs. year of release was similar for rainfed maize in both states: $39 \%$ for the average state yield in Iowa and $44 \%$ in Nebraska (Fig. 4a and 4b). In contrast, the deviation from regression was much smaller for irrigated maize in Nebraska $\left(R^{2}=0.64\right)$, 


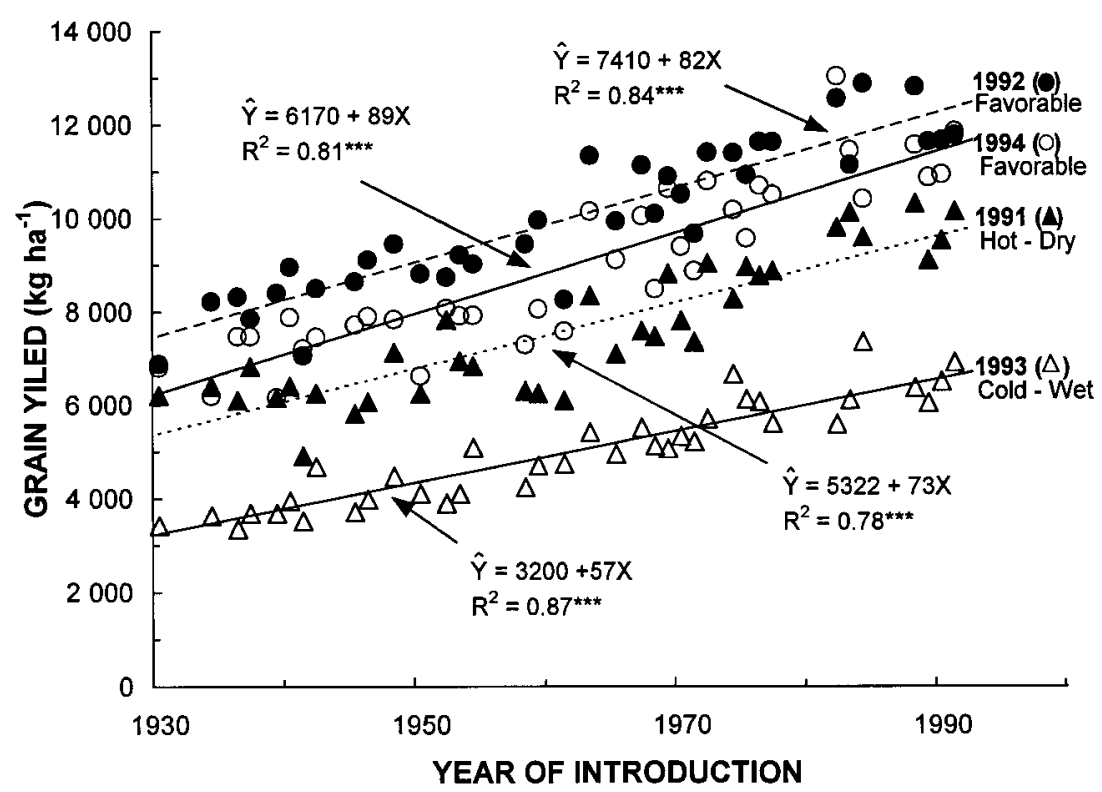

Fig. 3. Changes in the relationship between hybrid yield at the best plant density and year of release in field experiments conducted in different years at three locations in central Iowa.

although the rate of increase was similar at $93 \mathrm{~kg} \mathrm{ha}^{-1}$ $\mathrm{yr}^{-1}$ (Fig. 4b).

Although these rates of gain are impressive, they are considerably smaller than the annual relative rate of increase in global maize demand of $1.5 \%$ that is projected for the next $30 \mathrm{yr}$ (Rosegrant et al., 1999). For example, the linear rate of gain in yield of irrigated maize in Nebraska $\left(93 \mathrm{~kg} \mathrm{ha}^{-1} \mathrm{yr}^{-1}\right)$ represents a relative rate of gain of $1 \%$ when compared with the trend-line average yield of $9400 \mathrm{~kg} \mathrm{ha}^{-1}$ in 1997. In contrast, this same linear rate of gain in absolute yield represents a relative rate of gain of $1.4 \%$, based on the trend-line yield in 1966, which was only $6500 \mathrm{~kg} \mathrm{ha}^{-1}$ (Fig. 4b). In Iowa, the relative rate of gain in average rainfed maize yield was $1.6 \%$ in 1966 vs. $1 \%$ in 1997, based on a linear yield increase of $87 \mathrm{~kg} \mathrm{ha}^{-1} \mathrm{yr}^{-1}$ (Fig. 4a). Therefore, the relative increase in maize production from prime maize-growing states such as Iowa and Nebraska will be substantially less than the projected rate of increase in global maize demand unless the rate of yield gain can be increased substantially or production area greatly expanded.

\section{Yield Trends in Yield Contests}

It is difficult to measure crop yield potential because achieving a complete absence of stress throughout the growing season is not possible under most field conditions, particularly when field size is representative of production agriculture. Perhaps the closest approximation of yield potential at a production scale, which we shall call the attainable yield level, is the yield that can be achieved with the best available technology at a given site. Under such conditions, climate and hybrid characteristics are the primary determinants of yield. The yields achieved by farmers who win organized yield contests provide a reasonable estimate of the attainable yield level in a given year for a given region. For exam-
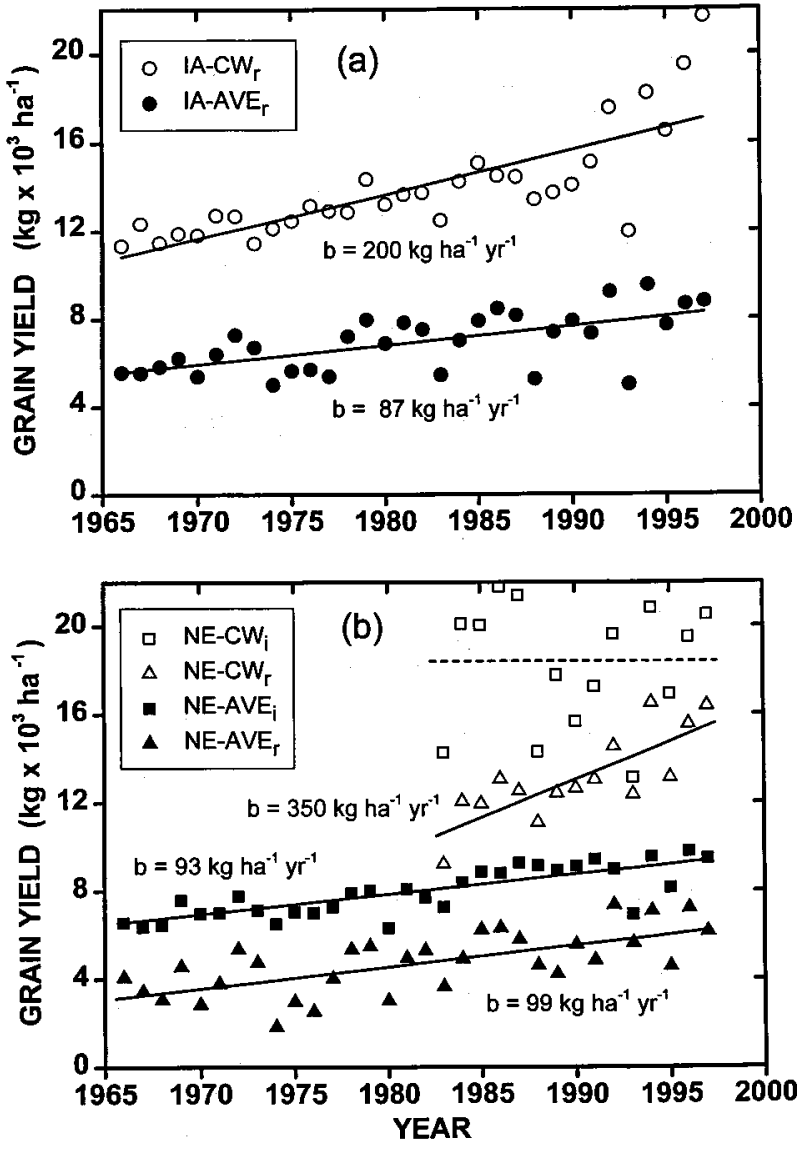

Fig. 4. Time trends in (a) Iowa contest-winning rainfed maize yields $\left(\mathrm{IA}-\mathrm{CW}_{\mathrm{r}}, \boldsymbol{R}^{2}=0.61\right)$ and Iowa average yields in rainfed systems (IA-AVE,$\left.R^{2}=0.39\right)$, and (b) Nebraska contest-winning yields in irrigated $(\mathrm{NE}-\mathrm{CW})$ and rainfed systems $\left(\mathrm{NE}-\mathrm{CW}, \boldsymbol{R}^{2}=\mathbf{0 . 6 4}\right)$, and state average yields from irrigated and rainfed systems $(\mathrm{NE}-\mathrm{AVE}$, $\left.R^{2}=0.64 ; \mathrm{NE}-\mathrm{AVE} \mathrm{E}_{\mathrm{r}}, \boldsymbol{R}^{2}=0.44\right)$. All regression coefficients are significant at $P<0.001$. The dashed horizontal line represents the mean irrigated contest-winning yield of $18200 \mathrm{~kg} \mathrm{ha}^{-1}$. 
ple, the Iowa Masters Corn Grower's Contest and the National Corn Growers Association Yield Contest in Nebraska involve hundreds of farmers who strive to achieve maximum possible yield from the fields they enter in the competition. Crops are managed with fullsize equipment, grain is harvested by combine, and yields are verified by independent observers and corrected to standard moisture content $\left(155 \mathrm{~g} \mathrm{~kg}^{-1}\right)$. We propose that the contest-winning yield trends provide a reasonable estimate of trends in the attainable yield level in both rainfed and irrigated systems. Because the contest-winning farmers continually change hybrids to represent the best available germplasm, many of the contest winners used hybrids that were included in the time-series study discussed in the previous section.

In rainfed systems, contest-winning yields since 1966 have advanced by $200 \mathrm{~kg} \mathrm{ha}^{-1} \mathrm{yr}^{-1}$ in Iowa and $350 \mathrm{~kg}$ $\mathrm{ha}^{-1} \mathrm{yr}^{-1}$ since 1983 in Nebraska (Fig. 4a and 4b). These rates of increase are two to three times greater than the absolute rate of gain in statewide average yields. Indeed, this widening yield gap was cited as evidence that the exploitable gap between average and attainable yield levels is not likely to close in the foreseeable future (Waggoner, 1994; Evans, 1993). However, the lack of an increasing yield trend for irrigated maize contest winners in Nebraska suggests a different scenario (Fig. 4b). Attainable yield levels with irrigation have varied by year with a mean yield level of $18200 \mathrm{~kg} \mathrm{ha}^{-1}$. Lower than average attainable yield levels were obtained in the flood year of 1993 that caused late planting, and in the hot and dry years of 1983 and 1988.

The lack of a trend in irrigated contest-winning yields suggests that yield potential, as defined by Evans (1993), has not increased during the past $15 \mathrm{yr}$ if we assume that contest-winning farmers used the best available maize hybrids at each point in time and management practices that provide growth conditions with minimal stress. Other reports of record rainfed maize yields in the 21000 to $23000 \mathrm{~kg} \mathrm{hg}^{-1}$ range extend back to the mid 1970s (Table 3). It appears, therefore, that there has been little change in maize yield potential during the past $25 \mathrm{yr}$. Based on the mean yield of irrigated contest winners in Nebraska since 1983, the average maximum attainable yield level at a production scale appears to be $18200 \mathrm{~kg} \mathrm{ha}^{-1}$. It varies by year depending on solar radiation and temperature regime, and unusual climatic events such as heavy spring rains that delay planting, an early frost that shortens grain filling, or hot and dry weather during the anthesis-silking period, which reduces pollination and seed set. It is noteworthy that the most recent contest-winning yield in the rainfed Iowa Master's Contest approached $22000 \mathrm{~kg} \mathrm{ha}^{-1}$ (Fig.

Table 3. Highest reported rainfed maize yields in the north-central United States since 1975.

\begin{tabular}{|c|c|c|c|}
\hline Year & Grain yield & Location & Reference \\
\hline & $\mathbf{k g ~ h a}^{-1}$ & & \\
\hline 1975 & 21200 & McLean Co., IL & Nelson and Reetz, 1986 \\
\hline 1977 & 22110 & St. Joseph Co., MI & Robertson et al., 1978 \\
\hline 1985 & 23200 & McLean Co., IL & Nelson and Reetz, 1986 \\
\hline 1997 & 21650 & Delaware Co., IA & $\begin{array}{l}\text { Iowa Crop Improvement } \\
\text { Assoc., } 1998\end{array}$ \\
\hline
\end{tabular}

4a), which indicates a rainfed production environment that provided an ideal moisture regime for maize growth and development.

The trends in Fig. 4 suggest that attainable yield levels in rainfed systems in Iowa and Nebraska are converging on the attainable yield level of irrigated systems, and the latter appears to represent a yield ceiling in productionscale fields. This convergence suggests that the exploitable yield gap between maximum attainable yield levels and average yields achieved by farmers will begin to close during the next $30 \mathrm{yr}$, if average yields continue on the same linear trajectory of the past. On the other hand, if the absolute rate of yield increase were to accelerate to match the projected annual increase of $1.5 \%$ in global demand for maize, the exploitable yield gap will disappear rapidly without a concomitant increase in maize yield potential.

\section{The Challenge of Increasing Maize Yield Potential}

Evidence from direct comparison of historical maize hybrids, yield trends in irrigated yield contests, and reports of record yields provide conflicting evidence about trends in yielding ability of temperate maize hybrids released in the post-Green Revolution era. In the absence of published data for biomass, components of yield, leaf area index, leaf $\mathrm{N}$ content, and light interception when the maize crop achieves yield potential levels in the north-central United States, we propose that the yield levels achieved in the irrigated contests and the reports of record rainfed yields provide the best estimate of maize yield potential. In contrast, yields in the rainfed time-series comparisons are well below these yield levels. We therefore conclude there is little compelling evidence that the yield potential of maize hybrids adapted to the north-central United States has increased during the past $25 \mathrm{yr}$.

However, it should be recognized that each of these sources of information about trends in maize yield potential have weaknesses. Hence, our conclusion that maize yield potential has been stagnant is provisional. The time-series studies were conducted under rainfed conditions and with management practices that did not allow full expression of genetic yield potential. Therefore, the maize crops in these studies experienced stress of some kind during the growing season. In contrast, although the yield levels achieved in the irrigated yield contests probably approach yield potential levels, the lack of climate and soil data and plant measurements make it impossible to provide a functional model that can explain such high yields. Another issue is that some of the plant traits found to change in the time-series study of maize hybrids should theoretically contribute to greater yield potential. Direct measurements of climate, soil, and plant traits that determine grain yield must be made on a time-series of maize hybrids grown at yield potential levels to determine if these traits have contributed to an increase in maximum attainable yield levels.

Despite the apparent lack of increase in yield potential of maize in the north-central United States, it is clear 
that breeders have made tremendous progress toward increasing resistance to abiotic and biotic stresses. This conclusion is supported by the changes in plant traits measured in the time-series comparison (Table 2), as well as by the detailed greenhouse and field studies conducted by Tollenaar et al. (1994) on maize hybrids adapted to southern Canada. In fact, the increasing stress tolerance of commercial maize hybrids allows effective use of intensive agronomic practices, such as higher plant density and greater nutrient inputs. These intensive practices place greater competitive pressure on individual plants for water and light, and they provide a more conducive environment for increased pressure from certain diseases and insect pests.

Assuming that raising the yield potential ceiling is a high priority and that maize yield potential has been stagnant, what are the prospects for boosting the genetic yield limits of this crop? While it is always dangerous to speculate about the future, two points seem relevant. First, the efficiency of achieving gains in average maize yields in relation to the amount of investment in maize breeding has decreased by $75 \%$ during the past $30 \mathrm{yr}$. This decrease is evident from the four fold increase in inflation-adjusted dollars spent on maize improvement in the United States (Table 1), and the linear rate of increase in maize yields achieved by maize producers in Iowa and Nebraska during the same period (Fig. 4). The second point is that there has been a major shift in the emphasis of investments in maize improvement. With the advent of biotechnology and intellectual property rights, an increasing share of private-sector research is now directed toward the enhancement of end-use quality and identity-preserved traits, which are often unrelated to yield or, in some cases, come at the expense of yield potential (e.g., high-oil maize). At the same time, minimal public-sector funds are available for research on understanding the physiological basis of crop yield potential and the agronomic practices required to achieve it while preserving environmental quality. The perceived "problem" of commodity surpluses and low prices make funding of such research out of favor. Hence, the limited amount of public-sector funding for yield-potential research in the United States is directed mostly toward molecular approaches.

Without deeper understanding of the physiological determinants of maize yield potential, it is our belief that molecular approaches that seek to empirically concentrate "yield genes" are likely to fail. Instead, molecular geneticists must actively collaborate with crop physiologists, agronomists, and plant breeders so that genetic differences in yield potential can be properly measured and identified. Transgenic genotypes offer new approaches for testing hypotheses about rate-limiting processes, while advanced information technologies allow greater precision in real-time measurement of plant status in relation to environmental conditions and management practices. Such understanding will be crucial for breeders to develop new hybrids with greater yield potential. Additionally, as suggested above, measurement of yield-determining plant traits should be made on a time-series of maize hybrids grown at yield-potential levels, to determine if the changes in hybrid characteristics of the past $30 \mathrm{yr}$ have contributed to an increase in yield potential. Finally, we recommend that maize breeders and agronomists initiate hybrid performance tests at sites specifically selected for high yield potential, in addition to the widespread testing that occurs under typical farm conditions. Such "yield potential" testing sites would have a climate conducive to high yield potential, good soil quality, and access to irrigation. Relatively simple experimental designs could be employed to compare hybrid yields at the "typical" and "yield potential" sites to test for significant genotype $\times$ environment interactions. Evidence for or against such interactions would help guide breeders' choice of germplasm for development of new hybrids. The same germplasm would also provide experimental materials for investigation of the physiological determinants of maize yield potential and the agronomic practices required to express it.

\section{ACKNOWLEDGMENTS}

The authors thank Mr. John R. Green, Director of Production and Education in the National Corn Growers Association (NCGA), for providing the yield data for the Nebraska yield contests sponsored by the NCGA, and Mr. Kamil Haliloglu and Dan Latenser for preparing the figures.

\section{REFERENCES}

Bolanos, J., and G.O. Edmeades. 1996. The importance of the anthesis-silking interval in breeding for drought tolerance in tropical maize. Field Crops Res. 48:65-80.

Castelberry, R.M., C.W. Crum, and C.F. Krull. 1983. Genetic yield improvement of U.S. maize cultivars under varying fertility and climate environments. Crop. Sci. 24:33-36.

Derieux, M., M. Darrigrand, A. Gallais, Y. Barriere, D. Bloc, and Y. Montalant. 1987. Estimation du progrès genétique réalisé chez le mais grain en France entre 1950 et 1985. Agronomie 7:1-11.

Duncan, W.G., W.A. Williams, and R.S. Loomis. 1967. Tassels and the productivity of maize. Crop Sci. 7:37-39.

Duvick, D.N. 1981. Genetic diversity in corn improvement. p. 48-60. In H.D. Loden and D. Wilkinson (ed.) Thirty-Sixth Annual Corn and Sorghum Research Conference. Chicago, IL. 9-11 Dec. 1981 American Seed Trade Association, Washington, DC.

Duvick, D.N. 1984a. Genetic diversity in major farm crops on the farm and in reserve. Econ. Bot. 38:161-178.

Duvick, D.N. 1984b. Genetic contributions to yield gains of U.S. hybrid maize, 1930 to 1980 . p. 15-47. In W.R. Fehr (ed.) Genetic contributions to yield gains of five major crop plants. CSSA Spec. Publ. 7. ASA and CSSA, Madison, WI.

Duvick, D.N. 1992. Genetic contributions to advances in yield in U.S. maize. Maydica 37:69-79.

Duvick, D.N. 1997. What is yield? p. 332-335, In G.O. Edmeades et al. (ed.) Developing drought- and low N-tolerant maize. Proceedings of a Symposium. 25-29 March 1996. CIMMYT, México, D.F.

Duvick, D.N., and S.W. Noble. 1978. Current and future use of cytoplasmic male sterility for hybrid seed production. p. 265-277. In D.B. Walden (ed.) Maize breeding and genetics. John Wiley \& Sons, New York.

Evans, L.T. 1993. Crop evolution, adaptation, and yield. Cambridge Univ. Press, Cambridge, UK.

Eyhérabide, G.H., A.L. Damilano, and J.C. Colazo. 1994. Genetic gain for grain yield of maize in Argentina. Maydica 39:207-211.

Frey, K.J. 1996. National plant breeding study-1: Human and financial resources devoted to plant breeding research and development in the United States in 1994. Iowa Agric. and Home Econ. Experiment Station, and Cooperative State Research, Education \& Extension Service/USDA, Ames, IA. Special Report. no. 98.

Iowa Crop Improvement Association. 1998. Iowa Crop Improvement 
Assoc. [Online]. Available at www.agron.iastate.edu/ICIA (verified 21 June 1999).

Ivanovic, M., and L. Kojic. 1990. Grain yield of maize hybrids in different periods of breeding. Informatsionnyi Byulleten po Kukuruza 8:93-101.

Kalton, R.R., P.A. Richardson, and N.M. Frey. 1989. Inputs in private sector plant breeding and biotechnology research programs in the United States. Diversity 5:22-25.

McDermitt, D.K., and R.S. Loomis. 1981. Elemental composition of biomass and its relation to energy content, growth efficiency, and growth yield. Ann. Bot. 48:275-290.

Nelson, W.L., and H.F. Reetz. 1985. Herman Warsaw's high corn yields. Crops Soils 38(8):5-7.

National Research Council. 1972. Genetic vulnerability of major crops. National Research Council, National Academy of Sciences, Washington, DC

Pioneer Hi-Bred International. 1973-1997. Annual reports. Pioneer Hi-Bred International, Des Moines, IA.

Robertson, L.S., D.D. Warncke, and D.L. Mokma. 1978. Test levels in profiles of two soils producing world-record corn yields. Re- search no. 363. Michigan Agricultural Experiment Station, East Lansing.

Rosegrant, M.W., N. Leach, and R.V. Gerpacio. 1999. Alternative futures for world cereal and meat consumption. Summer meeting of the Nutrition Society. Guildford, UK. 29 June-2 July 1998. Proc. Nutr. Soc. 58:1-16.

Russell, W.A. 1991. Genetic improvement of maize yields. Adv. Agron. 46:245-298.

Tollenaar, M. 1991. Physiological basis of genetic improvement of maize hybrids in Ontario from 1959 to 1988. Crop Sci. 31:119-124.

Tollenaar, M., D.E. McCullough, and L.M. Dwyer. 1994. Physiological basis of the genetic improvement of corn. p. 183-236. In G.A Slafer (ed.) Genetic improvement of field crops. Marcel Dekker, New York.

Tollenaar, M., and J. Wu. 1999. Yield improvement in temperate maize is attributable to greater stress tolerance. Crop Sci. 39:15971604 (this issue).

Waggoner, P.E. 1994. How much land can ten billion people spare for nature? Council for Agriculture, Science, and Technology, Ames, IA.

\section{Intellectual Property Rights, Access to Plant Germplasm, and Crop Production Scenarios in 2020}

\section{R. E. Evenson*}

\begin{abstract}
The scope of intellectual property rights (IPRs) has been expanded in recent years to cover plant varieties. Plant breeders' rights (PBRs) provide weak protection to private plant breeders in many countries. The United States and a few other developed countries provide patent protection to plant varieties as well as to some genetic resources. In principle, the strengthening of IPRs for plants should encourage more plant breeding and more variety options for farmers. However, developing countries often lack the institutional setting to enable them to realize these options. A second type of IPR providing for 'farmers' rights" has been prepared in the Convention on Biodiversity. Negotiating a payment framework for farmers' rights may result in a period of limited international exchange of genetic resources. Policy simulations based on an international economic model confirm that developing countries will be harmed by weak IPRs while developed countries will not be affected. They also confirm that both developing and developed countries will be harmed by reduced exchange of genetic resources associated with protracted negotiations over farmers' rights.
\end{abstract}

U NTIL RECENTLY, intellectual property rights were of limited relevance to plant breeding activities. In fact, because IPRs were not applied to plants and animals, private-sector firms had little incentive to engage in plant breeding activities (except in crops where hybridization requires new seed production for each crop). Public-sector plant breeding programs in both national agricultural research systems (NARs) and international agricultural research centers (IARCs) were (and remain) the chief producers of improved crop varieties. The public-sector research "culture" has a long tradition of open sharing of genetic resources, germplasm, and research findings between research centers. Extensive collections of landraces, mutants, wild species, weedy relatives, and advanced breeding lines exist for most

Economics Department, Yale University, 27 Hillhouse Avenue, New Haven, CT 06520. Received 28 Dec. 1998. *Corresponding author (robert.evenson@yale.edu).

Published in Crop Sci. 39:1630-1635 (1999). important crops. For an economic evaluation of these resources, see Evenson et al. (1998).

This tradition of open sharing and exchange of genetic materials is under challenge from recent developments in IPR coverage and implementation. In the 1960s and 1970s, PBRs were implemented in many developed economies and this encouraged an expansion of privatesector plant breeding programs. In the 1980s, two developments led to an expansion of patent rights to plants and animals. One was the rapid development of biotechnology research methods. The second was the court-led expansion of patent rights to cover multicellular living plants and animals. These two developments are related. New biotechnology methods enable the invention of plants and plant components to meet the traditional standards of invention. Court rulings expanding protection have responded to this by allowing the application of these standards. In the 1990s, these stronger patent rights (and other IPRs) have been incorporated into world trade agreements, requiring many developing countries to address IPR issues for the first time.

\section{The Application of Intellectual Property Rights to Plants}

There are three IPRs of relevance to plants. The oldest type is the specialized "plant patent." In the United States, the 1930 Plant Patent Act provided patent-like protection to asexually reproduced plants. This right gives the holder the "right to exclude" (without permission) others from reproducing the protected material. These rights have been important primarily for ornamental plants.

Of wider usage are PBRs. The Plant Variety Protec-

Abbreviations: IARCs, international agricultural research centers; IFPRI, International Food Policy Research Institute; IMPACT; International Model for Policy Analysis of Agricultural Commodities; IPRs, intellectual property rights; NARs, national agricultural research systems; PBRs, plant breeders rights; TFP, total factor productivity. 